\title{
Carbon Sequestration Service of a Ramsar Site: A Conservation-Role Model for Defying Developmental Pressure in the Middle of a Rapidly Expanding City
}

\author{
Abdullah Sulaiman Al-Nadabi*, Hameed Sulaiman \\ Biology Department, College of Science, Sultan Qaboos University, Al-Khod, Oman \\ Email: *a.alnadabi53@gmail.com, hanhameco@gmail.com
}

How to cite this paper: Al-Nadabi, A. S., \& Sulaiman, H. (2021). Carbon Sequestration Service of a Ramsar Site: A Conservation-Role Model for Defying Developmental Pressure in the Middle of a Rapidly Expanding City. Open Journal of Forestry, 11, 381-397.

https://doi.org/10.4236/ojf.2021.114023

Received: September 12, 2021

Accepted: October 19, 2021

Published: October 22, 2021

Copyright $\odot 2021$ by author(s) and Scientific Research Publishing Inc. This work is licensed under the Creative Commons Attribution International License (CC BY 4.0).

http://creativecommons.org/licenses/by/4.0/

(c) (i) Open Access

\begin{abstract}
Mangroves in coastal cities are under threat due to development pressures. However, mangrove ecosystems can serve as a potential carbon sink for mitigating the impacts of climate change. The main objective of this study was to estimate the carbon sequestration potential of mangroves in the Al-Qurm natural reserve, Muscat, Oman. The reserve was classified into three distinct zones and was estimated through field measurement and remote sensing techniques. The study found that each zone sequesters varying levels of carbon. The highest mean carbon stock was measured in the landward zone $\left(20.2 \pm 0.3 \mathrm{~kg} \cdot \mathrm{C} / \mathrm{m}^{2}\right)$, followed by the middle zone $\left(8.7 \pm 0.4 \mathrm{~kg} \cdot \mathrm{C} / \mathrm{m}^{2}\right)$ and seaward zone $\left(5.8 \pm 0.8 \mathrm{~kg} \cdot \mathrm{C} / \mathrm{m}^{2}\right)$, respectively. The carbon sequestration rate of the sediment range was between $5.0 \mathrm{~g} \mathrm{C} / \mathrm{m}^{2}$.year $-12.5 \mathrm{~g} \mathrm{C} / \mathrm{m}^{2}$.year. Normalized difference vegetation index (NDVI) derived from above-ground biomass showed a positive relationship $(r=0.73)$ with biomass measured in the field. However, the average above-ground carbon was underestimated $\left(6.3 \mathrm{~kg} \cdot \mathrm{C} / \mathrm{m}^{2}\right)$ than the above-ground field measurement $\left(7.0 \mathrm{~kg} \cdot \mathrm{C} / \mathrm{m}^{2}\right)$. This $0.82 \mathrm{~km}^{2}$ of the natural reserve was estimated to sequester approximately 9512 tonnes of carbon equivalent to $0.035 \mathrm{Mt}$ of $\mathrm{CO}_{2} \mathrm{e}$. This highlights the importance of conserving this natural reserve, despite a growing demand for land use in and around the reserve for development needs.
\end{abstract}

\section{Keywords}

Biomass, Carbon Sequestration, Mangroves, Remote Sensing, Cities

\section{Introduction}

Conservation of mangroves in urban areas has the potential for carbon regula- 
tion. Mangroves can assist to remedy carbon dioxide emissions from accelerated residential, industrial, commercial land uses in urban development by sequestrating and storing carbon for long periods (Fan et al., 2020; Friess et al., 2015). They can store large amounts of carbon per unit area (Kandasamy et al., 2021; Njana et al., 2015), with the capacity to sink carbon 3 to fivefold compared to terrestrial forests (Alavaisha \& Mangora, 2016; Tue et al., 2014). In addition, they respond very well to a higher concentration of $\mathrm{CO}_{2}$ in the atmosphere. Strategies to combat climate change have shifted from reducing emissions to an integrated approach that involves the conservation of high carbon storage ecosystems. Mangrove forests have been identified as an essential sink in climate change mitigation strategies.

Accurate estimation of carbon stocks is necessary before taking any measures towards conservation and restoration (Liu et al., 2014). Over the years, there have been several studies on carbon sequestration of mangrove wetlands in China (Li et al., 2006), Malaysia (Hamdan et al., 2013), India (Manna et al., 2014; Patil et al., 2013; Sahu et al., 2016), Indonesia (Winarso et al., 2017), Australia (Tran, 2014). However, little is known about the importance of mangrove wetlands in hyper-arid regions. The Sultanate of Oman has ratified the United Nations Framework Convention on Climate Change (UNFCCC) and signed the 2016 Paris agreement. It has initiated measures to achieve the objectives of this agreement. Assessing the contribution of the natural ecosystem as a mitigation measure has not been explored. Therefore, this study estimated carbon sequestration potential by mangroves in the Al-Qurm nature reserve in Muscat city. The study estimated above and below-ground carbon stock through field measurement and remote sensing. In addition, organic carbon storage and carbon sequestration potential (CSP) of the sediments were quantified. The study results may provide useful information to planners and policymakers, emphasizing the importance of maintaining and conserving natural vegetation in cities like Muscat. By continuously committing to protect this study site under the law will project this nature reserve as a role model for conservation.

\section{Materials and Methods}

\subsection{Study Site}

The study area is the Al-Qurm nature reserve, located beside the coastal area of the Oman Sea in Muscat Governorate, Oman (Figure 1). This reserve occupies $171 \mathrm{ha}\left(1.7 \mathrm{~km}^{2}\right)$ of land within the Muscat capital area, which is located at $58^{\circ} 32^{\prime} 43.02^{\prime \prime} \mathrm{E}$ and $23^{\circ} 36^{\prime} 51.58^{\prime \prime} \mathrm{N}$ and contains about $82 \mathrm{ha}\left(0.82 \mathrm{~km}^{2}\right)$ of mangrove vegetation. The Government of Oman designated this reserved area for conservation under Royal Degree No. (38/1975). It was also recognized in 2013 as the first Ramsar site in Oman (MECA, 2014). A single strand of the Avicennia marina occupies the vegetation. The soil in the reserve is predominantly sandy loam (Cookson \& Lepiece, 1997). The tides are semidiurnal, with a mean tide height of about $2 \mathrm{~m}$. The mean annual temperature of this area is about $28.2^{\circ} \mathrm{C}$ 


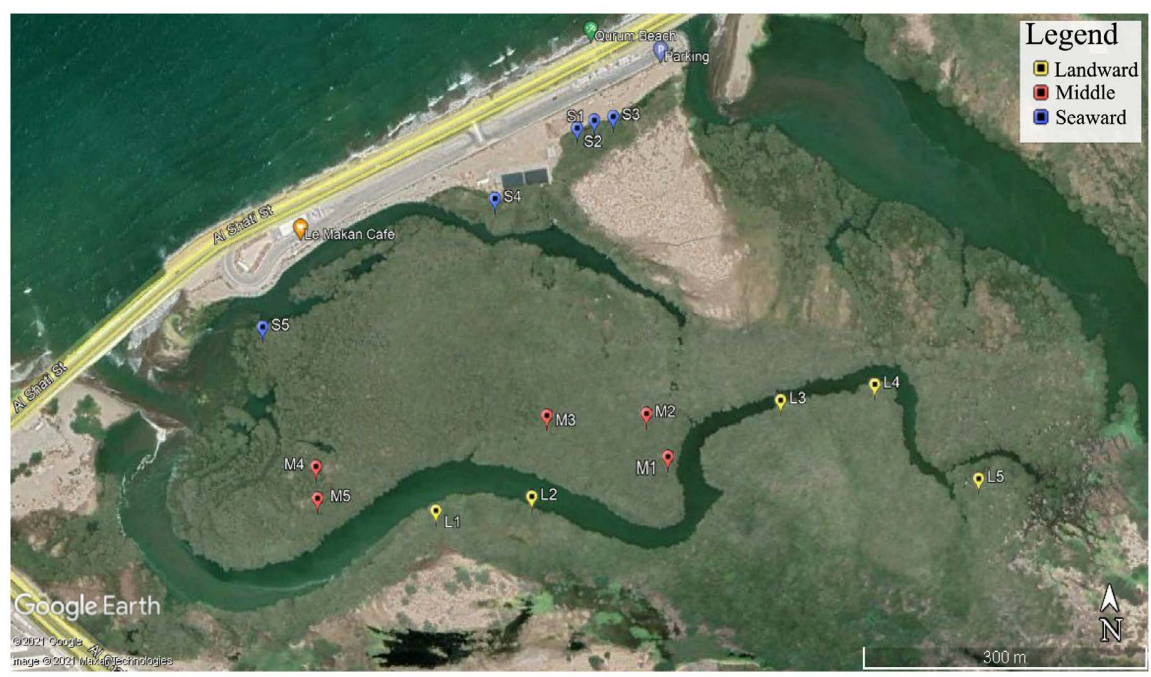

Figure 1. The location of sampling plots in the study area.

for the last 20 years (1995-2013). Precipitation is low, averaging $97.4 \mathrm{~mm}$ for the same period, and the average of solar radiation is high, with $535 \mathrm{~m} \mathrm{Wh} / \mathrm{sq} . \mathrm{cm}$ (Public Authority for Civil Aviation, 2017).

A stratified random sampling technique was employed to determine the carbon stock (Hamdan et al., 2013; Kovacs et al., 2010; Sahu et al., 2016). The study area was classified into 3 categories: seaward zone, middle zone, and landward zone, according to the structural appearance of vegetation. Five circular experimental plots per zone were established with an individual plot size of $200 \mathrm{~m}^{2}$. The locations of plots were randomly distributed within the accessible area of these zones (Figure 1). The coordinates of each plot were determined using a Global Positioning System (GPS-Garmin-62s). The diameter at breast height (DBH) of tree trunks was measured at 1.3 meters above the ground using a diameter tape. Since Avicennia marina species are multi-stemmed, each stem was treated as a separate tree (Clough et al., 1997; Patil et al., 2013). A total of 2754 stems were measured for DBH in 983 trees. The details of measurements for 3 zones were presented in Table 1.

\subsection{Above and Below-Ground Biomass}

Above and below-ground biomass were estimated using allometric equations developed by earlier researchers (Clough et al., 1997; Comley \& McGuinness 2005; Fromard et al., 1998). To get the best biomass estimation, we used 2 separate equations for greater than and less than $4 \mathrm{~cm} \mathrm{DBH}$ classes, as mentioned below.

$$
\begin{gathered}
\mathrm{AGB}=0.1776 * \mathrm{D}^{2.299}, \quad \mathrm{DBH}>4 \mathrm{~cm} \\
\mathrm{AGB}=200.4 * \mathrm{D}^{2.1} * 0.001, \quad \mathrm{DBH}<4 \mathrm{~cm} \\
\mathrm{BGB}=1.28 * \mathrm{D}^{1.17}, \quad \mathrm{DBH}>4 \mathrm{~cm} \\
\mathrm{BGB}=0.92307 * \mathrm{AGB}, \quad \mathrm{DBH}<4 \mathrm{~cm}
\end{gathered}
$$


Table 1. Field data for the three zones.

\begin{tabular}{ccccccc}
\hline Zone & $\begin{array}{c}\text { Total plots } \\
(\mathrm{n})\end{array}$ & $\begin{array}{c}\text { Average DBH }(\mathrm{cm}) \\
\text { Mean } \pm \text { SE }\end{array}$ & $\begin{array}{c}\text { Trees } \\
\text { number }\end{array}$ & $\begin{array}{c}\text { Number of } \\
\text { measurements }\end{array}$ & $\begin{array}{c}\text { Density of } \\
\text { trees/hectares (ha) }\end{array}$ & $\begin{array}{c}\text { Total sampled area } \\
\text { in hectares (ha) }\end{array}$ \\
\hline Landward & 5 & $8.9 \pm 0.24$ & 391 & 854 & 2390 & 0.1 \\
Middle & 5 & $5.3 \pm 0.14$ & 353 & 980 & 3530 & 0.1 \\
seaward & 5 & $4.6 \pm 0.13$ & 239 & 920 & 18030 & 0.1 \\
Total zones $=3$ & 15 & $6.29 \pm 0.17$ & 983 & 2754 & $3277 \pm 303$ & 0.3 \\
\hline
\end{tabular}

AGB is the above-ground biomass, BGB is the below-ground biomass, and D is the trunk diameter (Clough et al., 1997; Comley \& McGuinness, 2005; Fromard et al., 1998). Carbon stock was estimated from biomass using global default factors of 0.48 for AGB and 0.39 for BGB (Adame et al., 2015). Values are expressed in a kilogramme of carbon per meter square $\left(\mathrm{Kg} \cdot \mathrm{C} / \mathrm{m}^{2}\right)$. Furthermore, this estimated carbon was multiplied by 3.6663 to convert it to $\mathrm{CO}_{2}$ sequestered in the entire mangrove ecosystem (Patil et al., 2013).

The image of the study area with a spatial resolution of $30 \mathrm{~m} \times 30 \mathrm{~m}$ using path and row for Muscat Governorate of 158 and 43, 44, respectively, were acquired by Landsat 8 through the USGS Earth Explorer (earthexplorer.usgs.gov) (Figure 2). It was acquired on the 9th March 2017, corresponding to the period of the field measurement. Before calculating the NDVI, the image undergoes atmospheric correction to convert digital number values into surface reflectance using Environment for Visualizing Image (ENVI 5.0 software). It has been geometrically corrected by NASA using a digital elevation model (DEM). NDVI was calculated using the following formula (Manna et al., 2014).

$$
\mathrm{NDVI}=\mathrm{NIR}-\mathrm{R} / \mathrm{NIR}+\mathrm{R}
$$

where NIR (Near-infrared band), R (Red band). The red band in Landsat 8 is band $4(0.64-0.67 \mu \mathrm{m})$, and near-infrared is band $5(0.85-0.88 \mu \mathrm{m})$. NDVI is based on the characteristics that vegetation has noticeable absorption in the red region of the electromagnetic spectrum and very strong reflectance in the near-infrared spectrum.

The regression model between field calculated above-ground biomass for all ground plots, and NDVI was established. Then, the derived equation from this relationship was utilized to predict the above-ground biomass and eventually above-ground carbon. Data of tree biomass AGB and BGB were statistically analyzed using Minitab 14 statistical software. One-way analysis of variance (ANOVA) was used to compare the 3 zones for AGC and BGC. Pearson's correlation was used to compare AGB results from field measurements and NDVI from remote sensing data.

\subsection{Sediment Investigation}

From the circular plots established for tree biometric measurement, 2 sediment samples were collected apart at a depth of $0-30 \mathrm{~cm}$ from each plot. The soil parameters, namely Total Organic Carbon (TOC) and bulk density, were analyzed 


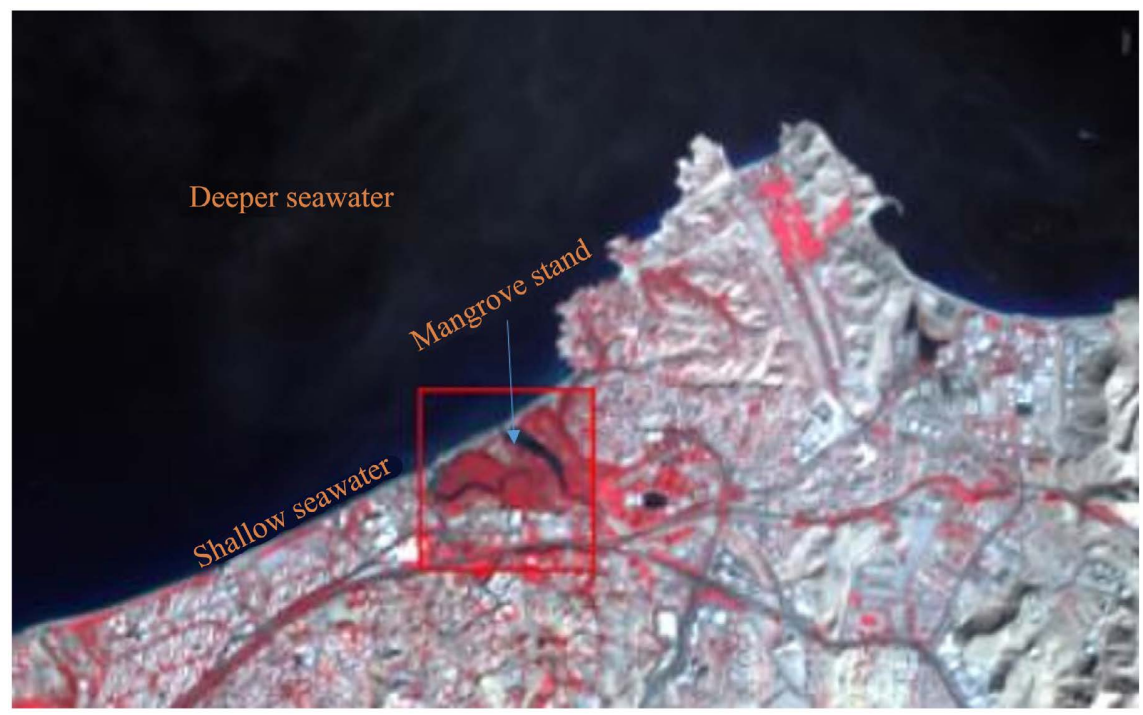

Figure 2. Landsat 8 image of study area.

using standard methods. TOC was analyzed using a TOC analyzer (SHIMADZU). Bulk density was calculated using the following equation.

Bulk density $=$ oven-dried weight/augur volume $\left(\pi r^{2} h\right)$, where $\pi=p i=3.14, r$ $=$ radius of augur $=1.25 \mathrm{~cm}, \mathrm{~h}=$ height of soil sample in the augur $(30 \mathrm{~cm})(\mathrm{Sa}-$ hu et al., 2016).

Soil organic carbon per hectare was calculated using the following formula.

Soil organic carbon $(\mathrm{t} / \mathrm{ha})=$ bulk density $\left(\mathrm{g} / \mathrm{cm}^{3}\right) *$ soil depth $(\mathrm{cm}) *$ organic carbon (\%) (Sahu et al., 2016).

Then, the amount was converted to $\mathrm{kg} / \mathrm{m}^{2}$ by dividing the result over ten. The carbon sequestration rate (CSR) was estimated based on soil bulk density (SBD), sedimentation rate $(\mathrm{R})$ and soil organic carbon concentrations (\%): CSR $\left(\mathrm{g} \cdot \mathrm{C} / \mathrm{m}^{2} \cdot\right.$ year $)=\mathrm{SBD} \times \mathrm{SOC}$ percentage $\times \mathrm{R}$, where $\mathrm{R}=($ the global mean $=2.8$ $\mathrm{mm} /$ year). CSP (carbon sequestration potential) ( $\mathrm{Gg} \mathrm{C} /$ year) was calculated as follows: CSP $=$ CSR $\times$ A, where A is an area occupied by mangroves (Eid et al., 2016).

\subsection{Total Ecosystem Carbon Storage}

The amount of carbon storage $\left(\mathrm{kg} \cdot \mathrm{C} / \mathrm{m}^{2}\right)$ in the Al-Qurm Nature Reserve (QNR) was estimated by summing up the above-ground carbon (AGC) and below-ground carbon (BGC) and soil carbon stocks. The total carbon stock of the mangrove forest of QNR was scaled up by multiplying the overall mean ecosystem carbon stock for the 3 zones with the total area occupied with mangroves $\left(0.82 \mathrm{~km}^{2}\right)$. It was converted to carbon dioxide $\left(\mathrm{CO}_{2}\right)$ equivalents $\left(\mathrm{CO}_{2} \mathrm{e}\right)$ by using a factor of 3.67 (Sahu et al., 2016).

\section{Results and Discussion}

The distribution of the DBH class showed a slightly reverse-J-shaped pattern that indicates an uneven age stand structure (Figure 3). This result was similar 


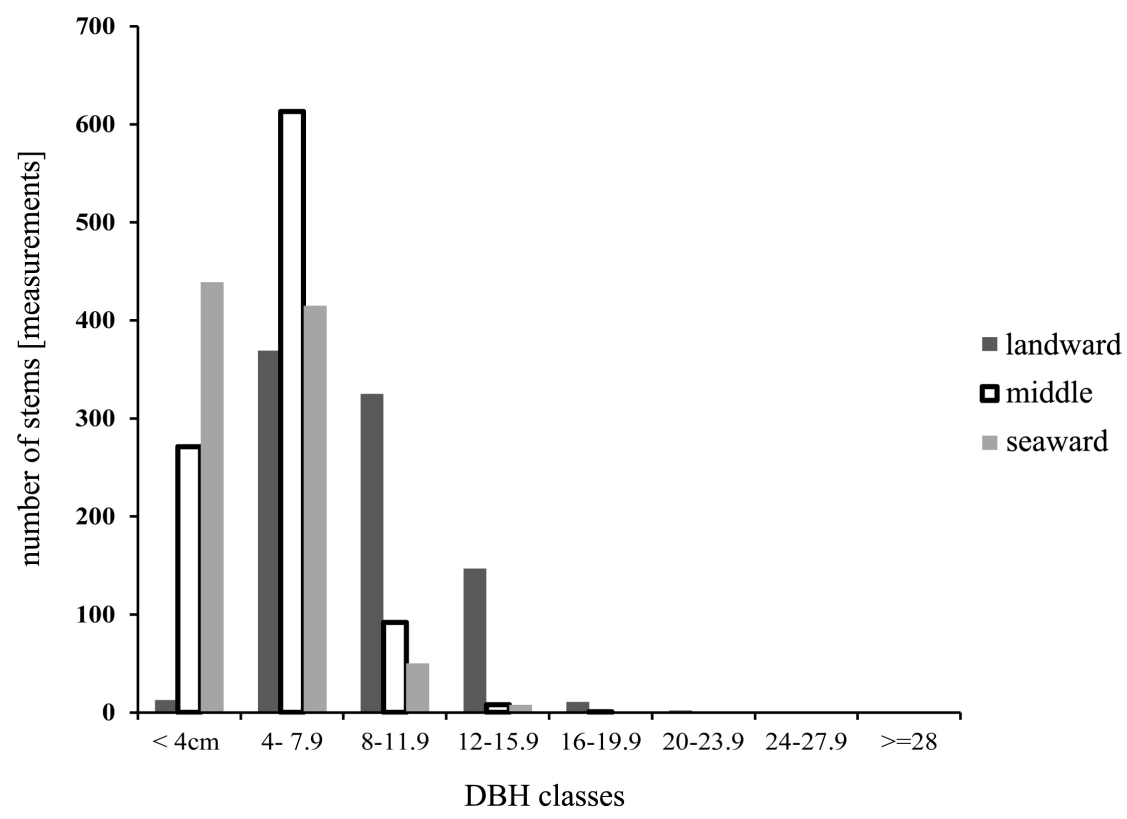

Figure 3. Frequency distribution of DBH in three zones.

to Avicennia marina forests in Taiwan (Fan, 2008) and United Arab Emirates (Alsumaiti, 2014), suggesting active regeneration in these populations. The results from this study show that $26 \%$ of measured stems have a diameter of less than $4 \mathrm{~cm}$, half (51\%) ranging from $4-7.9 \mathrm{~cm}, 17 \%$ from $8-11.9 \mathrm{~cm}$, and only $6 \%$ of measured stems have a diameter greater than $12 \mathrm{~cm}$. This study was consistent with Fan (2008) study in Taiwan, where he found that few trees with DBH greater than $12 \mathrm{~cm}$ for the same species. A study by Alsumaiti (2014) found that in the neighboring United Arab Emirates, there were few trees with DBH greater than $20 \mathrm{~cm}$. However, there was a typical DBH distribution between the 3 zones. The highest percentage (60.7\%) of $<4 \mathrm{~cm} \mathrm{DBH}$ was found in the seaward zone. Most DBH class between $4-7.9 \mathrm{~cm}$ were measured in the middle zone (43.8\%) and $8-11.9 \mathrm{~cm}$ in the landward zone (69.6\%). The remaining DBH classes above $12 \mathrm{~cm}$ were predominantly (89.4\%) found in the landward zone. This indicates that most mature trees are located in the landward zone. This might be due to the enriched sediments in the landward zone, adapting a more robust roots, which enable more mechanical support to their above-ground weight.

The total above-ground biomass in this study was about $218.0 \mathrm{~kg} / \mathrm{m}^{2}$, and the total above-ground carbon was approximately $105.0 \mathrm{~kg} \cdot \mathrm{C} / \mathrm{m}^{2}$ (Table 2). Plot number one of the landward zones has the highest value of AGB estimation $\left(28.7 \mathrm{~kg} / \mathrm{m}^{2}\right)$ and AGC of $13.8 \mathrm{~kg} \cdot \mathrm{C} / \mathrm{m}^{2}$, while seaward plot 5 has the lowest value of AGB $\left(4.1 \mathrm{~kg} / \mathrm{m}^{2}\right)$ and AGC $\left(2.0 \mathrm{~kg} \cdot \mathrm{C} / \mathrm{m}^{2}\right)$. The overall average in this study $\left(14.5 \mathrm{~kg} / \mathrm{m}^{2}\right)$ was comparable with the result in Egypt by Mashaly et al. (2016), East Coast of India by Sahu et al. (2016). It was slightly higher than results obtained by Dodd et al. (1999) in the neighboring United Arab Emirates and higher than the result estimated by Parvaresh et al. (2012) in Iran and Abohassan 
Table 2. Vegetation biomass $\left(\mathrm{kg} / \mathrm{m}^{2}\right)$ and carbon storage $\left(\mathrm{kg} \mathrm{C} / \mathrm{m}^{2}\right)$ partitioned between shoots (aboveground carbon, AGC) and roots (belowground carbon, BGC) in three zones.

\begin{tabular}{ccccc}
\hline Zone & $\begin{array}{c}\text { AGB } \\
\text { Aboveground } \\
\text { biomass }\end{array}$ & $\begin{array}{c}\text { AGC } \\
\text { Aboveground } \\
\text { carbon }\end{array}$ & $\begin{array}{c}\text { BGB } \\
\text { Belowground } \\
\text { biomass }\end{array}$ & $\begin{array}{c}\text { BGC } \\
\text { Belowground } \\
\text { carbon }\end{array}$ \\
\hline Average landward & 27.6 & 13.3 & 14.3 & 5.5 \\
Average middle & 9.5 & 4.6 & 8.1 & 3.1 \\
Average seaward & 6.5 & 3.1 & 5.7 & 2.2 \\
Total (15 study plots) & 217.9 & 104.7 & 154.8 & 60.4 \\
Overall average & 14.5 & 7.0 & 9.4 & 3.6 \\
\hline
\end{tabular}

et al. (2012) in the Kingdom of Saudi Arabia. In contrast, it is lower than the result calculated by Tran (2014) in Australia. Abohassan et al. (2012) mentioned that the global estimation for mangrove biomass is in the range of $0.68-43.6$ $\mathrm{kg} / \mathrm{m}^{2}$, where Avicennia marina fell in the lower range $<21.8 \mathrm{~kg} / \mathrm{m}^{2}$. However, an AGB $34.1 \mathrm{~kg} / \mathrm{m}^{2}$ for Avicennia marina forest was reported by Komiyama et al. (2008). The result of this study on Avicennia marina single stand of mangrove was within the range of $0.68-43.6 \mathrm{~kg} / \mathrm{m}^{2}$ but less than $21.8 \mathrm{~kg} / \mathrm{m}^{2}$. These biomass variations are influenced by factors such as tree height, geographical location, density, growth forms, and age of the mangrove plant community. One-way analysis of variance (ANOVA) was used to test the above-ground biomass between zones and illustrated in Figure 4. It showed a significant difference $(P<0.001)$ in the mean AGB between the 3 zones. The average AGB and AGC content can be ordered as follows: landward $>$ middle $>$ seaward. The range of overall AGB in this study was $4.1-28.7 \mathrm{~kg} / \mathrm{m}^{2}$ and AGC $2.0-13.8$ $\mathrm{kg} \cdot \mathrm{C} / \mathrm{m}^{2}$. Komiyama et al. (2008) reported that the AGB of Avicennia sp. tends to be relatively low in stands near the sea and increases inland.

Few allometric equations are available to estimate the BGB and eventually BGC for mangroves. This is mainly due to difficulties of complete extraction of roots from sediments and challenges associated with sampling in intertidal habitats (Abohassan et al., 2012; Komiyama et al., 2008). According to Abohassan et al. (2012), Avicennia marina roots are concentrated at the top $30 \mathrm{~cm}$ below the ground and spreading around the tree. The available allometric equations generated by Comley and McGuinness (2005) used in this study to estimate BGB found a strong relationship between DBH and BGB for Avicennia marina $(\mathrm{r}=$ $0.9)$.

The total BGB in the study sites was estimated to be about $155.0 \mathrm{~kg} / \mathrm{m}^{2}$ and BGC $60.0 \mathrm{~kg} \cdot \mathrm{C} / \mathrm{m}^{2}$ (Table 2). Plot number 5 of the landward zone has the highest value of $\mathrm{BGB}$ estimation $\left(14.7 \mathrm{Kg} / \mathrm{m}^{2}\right)$ and $\mathrm{BGC}\left(5.7 \mathrm{~kg} \cdot \mathrm{C} / \mathrm{m}^{2}\right)$, while seaward plot 5 has the lowest value of BGB $\left(4.2 \mathrm{~kg} / \mathrm{m}^{2}\right)$ and BGC $\left(1.6 \mathrm{~kg} \cdot \mathrm{C} / \mathrm{m}^{2}\right)$. Studies related to BGB of mangroves are limited globally, and most of these studies were conducted in Australia (Abohassan et al., 2012). The overall average in this study 
Boxplot of Aboveground biomass $\left[\mathrm{kg} / \mathrm{m}^{2}\right]$ by Zone

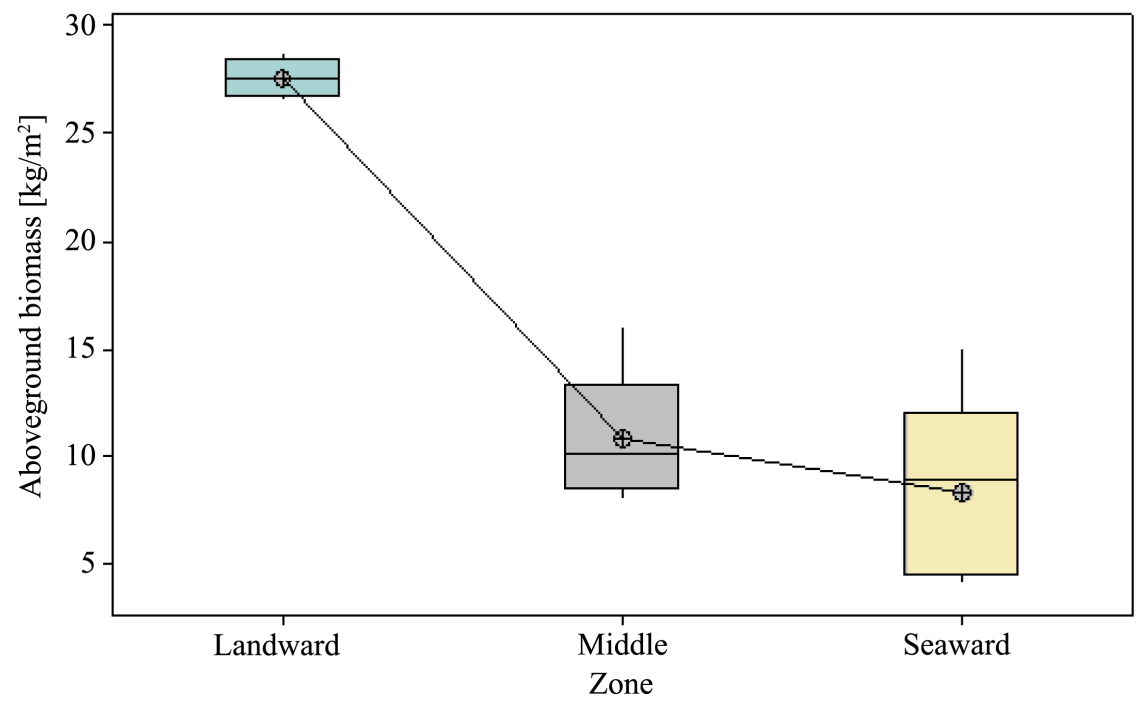

Figure 4. Analysis of variance of AGB between the three zones $(P<0.001)$.

was $9.4 \mathrm{~kg} / \mathrm{m}^{2}$. This value was close to the reported values from subtropical and hypersaline Australian environments Tran (2014) and slightly higher than the value recorded by Abohassan et al. (2012) in Saudi Arabia. In Kenya, the value of $4.1 \mathrm{~kg} / \mathrm{m}^{2}$ was estimated, which is lower compared to this study. While in Mahanadi mangrove wetland, on the east coast of India, the value ranges between $3.3-10.4 \mathrm{~kg} / \mathrm{m}^{2}$ (Sahu et al., 2016). Globally, the BGB of the Avicennia marina ranges from $1.5-16.6 \mathrm{~kg} / \mathrm{m}^{2}$ (Abohassan et al., 2012). The results from this study fall within this range. One-way analysis of variance (ANOVA) was used to test the below-ground biomass between zones and illustrated in Figure 5. It showed a significant difference $(P<0.001)$ in the mean BGC between the 3 zones. The average BGB and BGC content can be ordered as follows: landward > middle > seaward. The range of overall BGB in this study was $4.2-14.7 \mathrm{~kg} / \mathrm{m}^{2}$ and BGC $1.6-5.7 \mathrm{~kg} \cdot \mathrm{C} / \mathrm{m}^{2}$.

Table 3 shows a comparison of mean AGB and BGB in geographically neighboring arid countries. Estimates in this study are the highest. This can be attributed to Al-Qurm nature reserve's legal protection as a protected area, devoid of any human exploitation.

As reflected in the form of the Shoot/Root (T/R) ratio of the Avicennia mari$n a$, the above-ground and below-ground biomass varied between $1.0-2.1$ (Figure 6). Komiyama et al. (2008) reported that the T/R ratio of mangrove forests varied between $1.1-4.4$ and for Avicennia marina between $0.9-2.8$. The tree biomass distribution between above and below-ground showed variation between zones. In seaward and middle zones, about $40 \%$ of the biomass was below-ground and $60 \%$ above-ground. However, there was a shift in the landward zone, with $70 \%$ of the biomass in the above-ground and only $30 \%$ in the below-ground (Figure 7). Mangroves, in general, tend to allocate higher biomass to the root system. 
Boxplot of Belowground biomass $\left[\mathrm{kg} / \mathrm{m}^{2}\right]$ by Zone

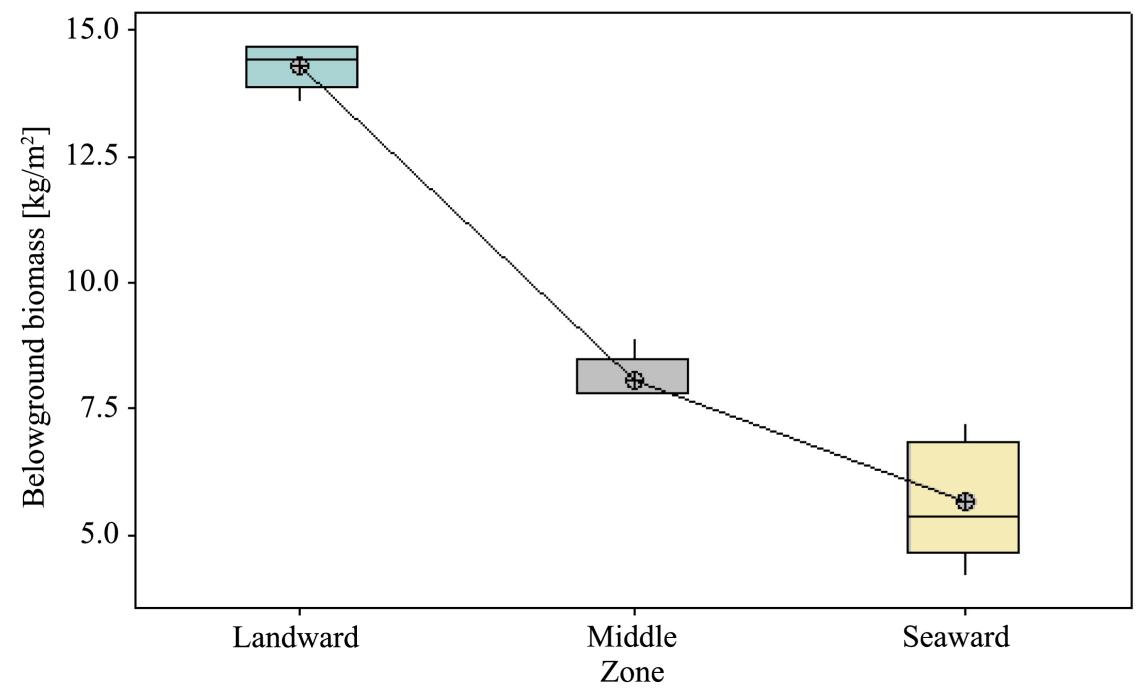

Figure 5. Analysis of variance of BGB between the three zones $(P<0.001)$.

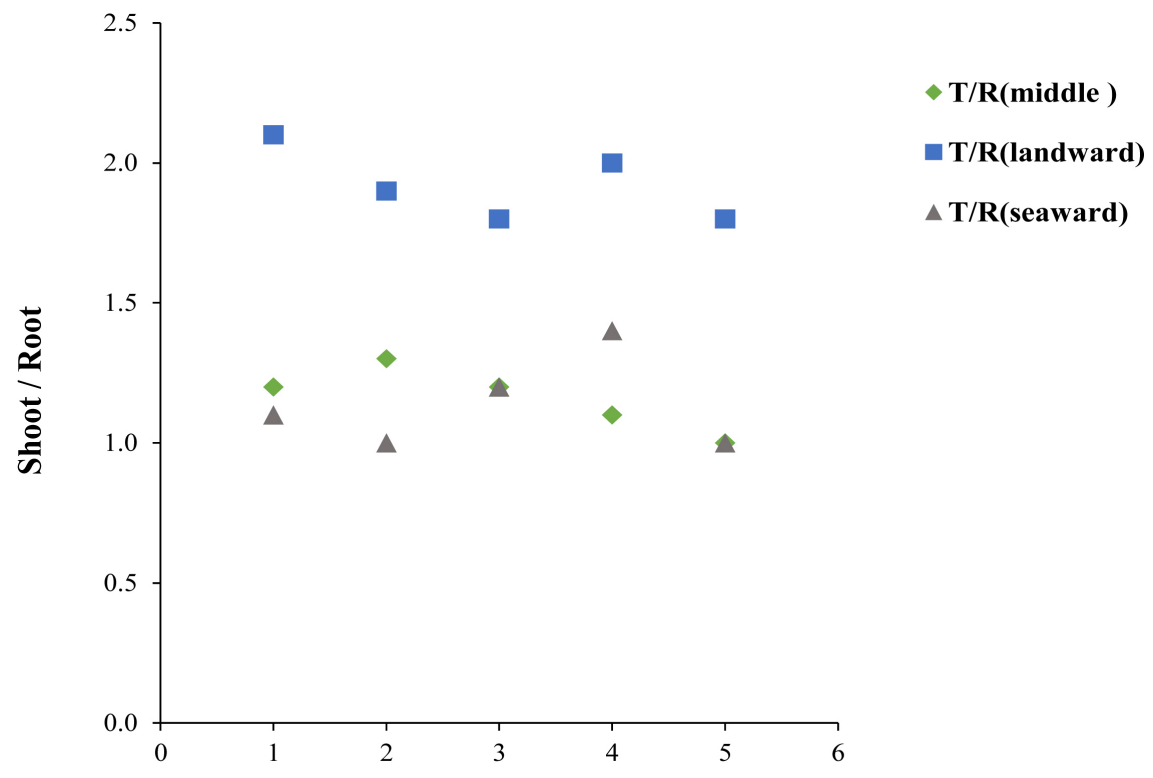

Plots of study area

Figure 6. Shoot to root ratio for Avicennia marina in the plots of study area.

Table 3. Biomass of Avicennia marina in the arid regions of neighboring countries.

\begin{tabular}{cccc}
\hline AGB $\left(\mathrm{kg} / \mathrm{m}^{2}\right)$ & BGB $\left(\mathrm{kg} / \mathrm{m}^{2}\right)$ & Study site & Reference \\
\hline 1.5 & 6.8 & KSA & Abohassan et al. (2012) \\
13.0 & 8.8 & Egypt & Mashaly et al. (2016) \\
1.7 & - & Iran & Parvaresh et al. (2012) \\
9 & - & UAE & Dodd et al. (1999) \\
1.3 & - & UAE & Alsumaiti (2014) \\
14.5 & 9.4 & This study (Al-Qurm & - \\
& & nature reserve), Oman & \\
\hline
\end{tabular}




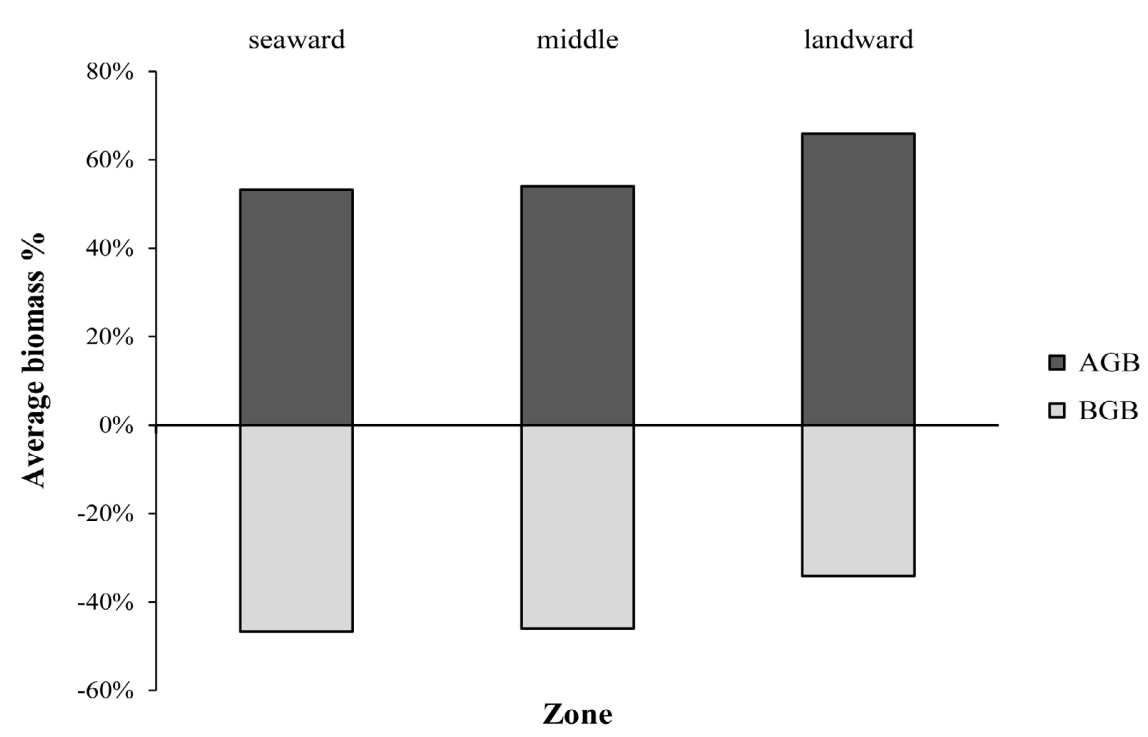

Figure 7. Biomass distribution between AGB and BGB.

Pearson correlation coefficient $(R)$ and coefficient of determination $\left(R^{2}\right)$ was calculated between estimated AGB and BGB (Figure 8). The correlation coefficient was 0.98 , which indicates a strong positive correlation between AGB and BGB, explaining $96 \%$ of the variance.

In estimating above-ground biomass using remote sensing, NDVI was used following the earlier studies (Hamdan et al., 2013; Manna et al., 2014; Patil et al., 2013; Winarso et al., 2017). A scatter plot between NDVI estimate and AGB calculated in the field was compared. The Pearson correlation coefficient and coefficient of determination were calculated to be 0.73 and 0.54 , respectively (Figure 9). The R-value indicates a moderate positive correlation. A regression equation was utilized to predict the AGB and amount of AGC that Avicennia marina could sequester. The maximum AGB predicted by the NDVI model was $22.5 \mathrm{~kg} / \mathrm{m}^{2}\left(10.8 \mathrm{~kg} \cdot \mathrm{C} / \mathrm{m}^{2}\right)$, which was lower than the result obtained from field measurements of $28.7 \mathrm{~kg} / \mathrm{m}^{2}\left(13.8 \mathrm{~kg} \cdot \mathrm{C} / \mathrm{m}^{2}\right)$. However, the overall average of AGB for the 3 zones was $14.5 \mathrm{~kg} / \mathrm{m}^{2}\left(7.0 \mathrm{~kg} \cdot \mathrm{C} / \mathrm{m}^{2}\right)$ and $13.1 \mathrm{~kg} / \mathrm{m}^{2}\left(6.3 \mathrm{~kg} \cdot \mathrm{C} / \mathrm{m}^{2}\right)$ from the field measurement and NDVI. In this study, it was slightly an underestimation of field biomass. In a similar study, NDVI underestimated the AGB since it was based only on the spectral response from the canopy of vegetation (Hamdan et al., 2013; Patil et al., 2013). The results from this study is consistent with the result obtained by Wicaksono et al. (2017), which found moderate relation between AGB and NDVI $\left(\mathrm{R}^{2}=0.54\right)$, while Winarso et al. (2017) found a low correlation $\left(\mathrm{R}^{2}=0.31\right)$ between NDVI and field biomass. Alternatively, Manna et al. (2014) obtained good correlations $\mathrm{R}^{2}=0.72, \mathrm{R}=0.68$, respectively. Hamdan et al. (2013) mentioned that using one vegetation index can significantly underestimate the biomass, so they suggested using more vegetation indices besides NDVI to overcome this problem. However, the difference in NDVI and field biomass between the 3 zones in this study was comparable, except for the middle zone (Figure 10). During field measurements, trees in landward and 


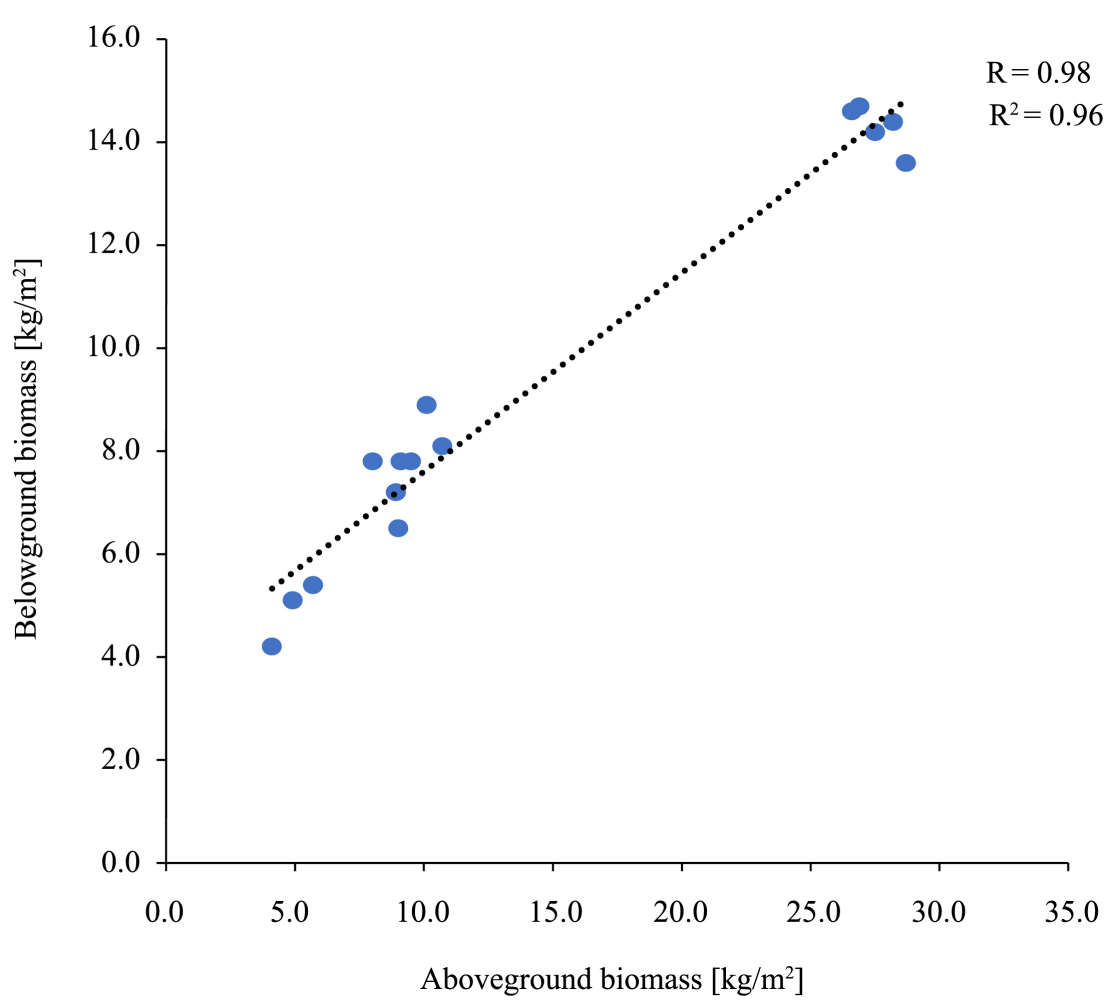

Figure 8. Relationship between AGB and BGB.

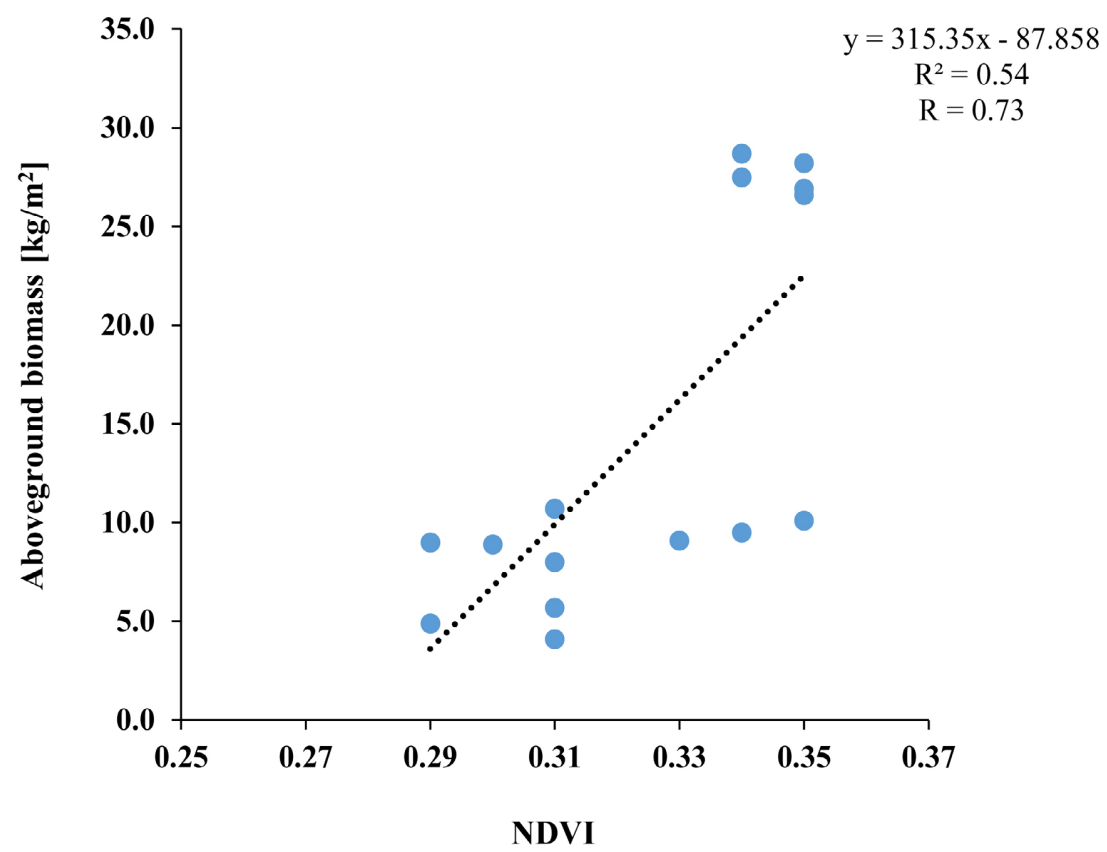

Figure 9. Relationship between measured AGB and NDVI.

seaward zones are closer to each other compared to the middle zone. Also, the trees in the middle zone were observed to have a more dead branches. These may be the reason for an overestimation of biomass from NDVI in the middle zone. 


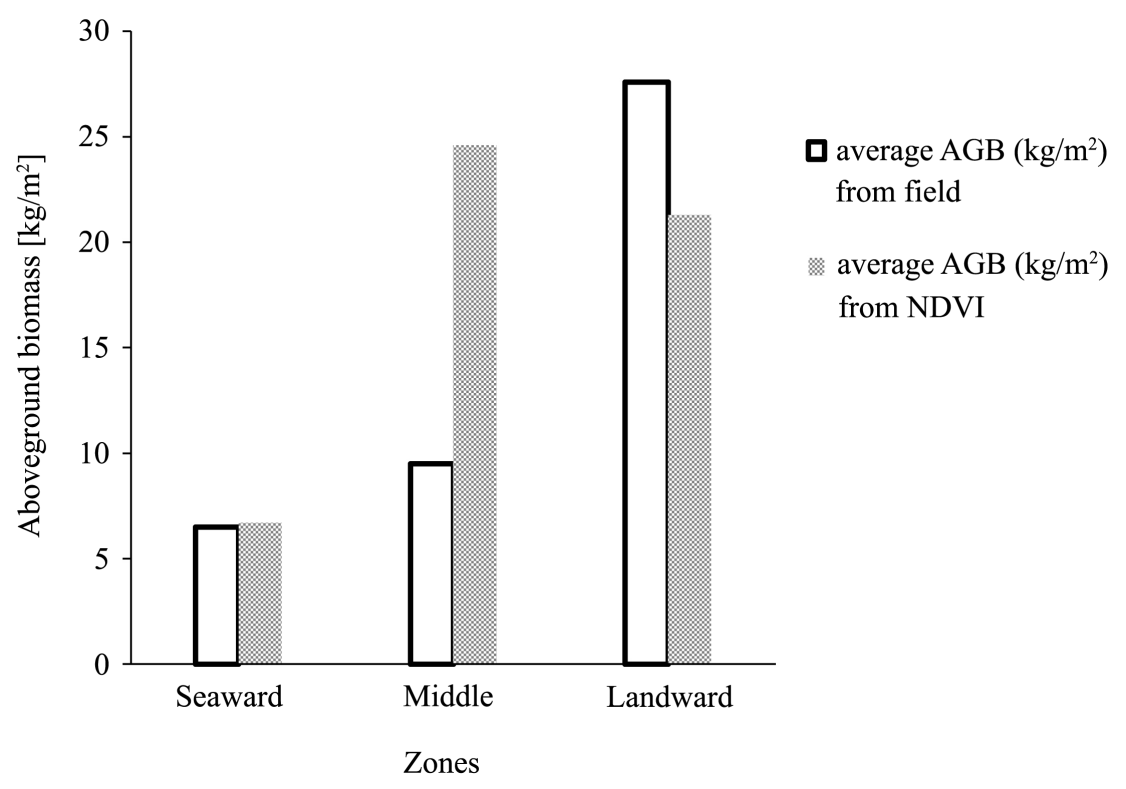

Figure 10. Average AGB from field measuremnt and NDVI.

Table 4 provides results of different sediment parameters in Al-Qurm Nature Reserve. Sediment organic carbon stored in the upper $30 \mathrm{~cm}$ depth of the sediment was in the range of $0.25-2.62 \mathrm{~kg} / \mathrm{m}^{2}$, with an average of $0.95 \mathrm{~kg} / \mathrm{m}^{2}$. The highest value was recorded in the landward plot, and this plot had the highest value of below-ground biomass. However, the lowest was recorded in the seaward plot, which also had the lowest biomass. These results demonstrate that biomass of mangroves is correlated with the amount of sediment organic carbon (SOC) in these habitats. The landward zone has a mean SOC of $1.36 \pm 0.58$ $\mathrm{kg} \cdot \mathrm{C} / \mathrm{m}^{2}$, followed by the middle zone $\left(0.97 \pm 0.49 \mathrm{~kg} \cdot \mathrm{C} / \mathrm{m}^{2}\right)$ and seaward zone $\left(0.52 \pm 0.24 \mathrm{~kg} \cdot \mathrm{C} / \mathrm{m}^{2}\right)$ respectively. The SOC pool shows variation between these 3 zones. The carbon sequestration rate (CSR) of mangrove was found to be in the range of $5.0 \mathrm{~g} \cdot \mathrm{C} / \mathrm{m}^{2} \cdot$ year $-12.5 \mathrm{~g} \cdot \mathrm{C} / \mathrm{m}^{2} \cdot$ year. Based on the area of mangroves in Al-Qurm Nature Reserve $\left(0.82 \mathrm{~km}^{2}\right)$ and CSR, the total carbon sequestration potential (CSP) was calculated as $0.007 \mathrm{Gg} \cdot \mathrm{C} /$ year. Statistical analysis using the one-way ANOVA showed a significant difference $(P<0.001)$ in the mean of sediment organic carbon (SOC) between the 3 zones (Figure 11).

The overall average of total organic carbon (TOC $\mathrm{g} / \mathrm{kg}$ ) and sediment organic carbon $\mathrm{kg} / \mathrm{m}^{2}$ (SOC) in this study was $3.6 \mathrm{~g} \mathrm{C} / \mathrm{kg}$ and $0.95 \mathrm{~kg} \cdot \mathrm{C} / \mathrm{m}^{2}$, respectively. Considering the entire sediment profile $(0-30 \mathrm{~cm})$, the average SOC pool in the mangrove $\left(0.95 \mathrm{~kg} \cdot \mathrm{C} / \mathrm{m}^{2}\right)$ was lower than the average reported by Kauffman et al. (2011) for mangrove sediments from Micronesia $\left(12.1 \mathrm{~kg} \cdot \mathrm{C} / \mathrm{m}^{2}\right.$ at $100 \mathrm{~cm}$ depth); Eid et al. (2016) for mangrove sediments from the Kingdom of Saudi Arabia (17- $\mathrm{kg} \mathrm{C} / \mathrm{m}^{2}$ at $40 \mathrm{~cm}$ depth); Eid and Shaltout (2016) for mangrove sediments from Egypt ( $8.6 \mathrm{~kg} \cdot \mathrm{C} / \mathrm{m}^{2}$ at $40 \mathrm{~cm}$ depth); Liu et al. (2014) for mangrove sediments from China $\left(11.8 \mathrm{~kg} \cdot \mathrm{C} / \mathrm{m}^{2}\right.$ at $100 \mathrm{~cm}$ depth). A comparison between this study and similar research in neighboring countries is presented in Table 5. 
Boxplot of Soil organic carbon $\left[\mathrm{kg} / \mathrm{m}^{2}\right]$ by Zone

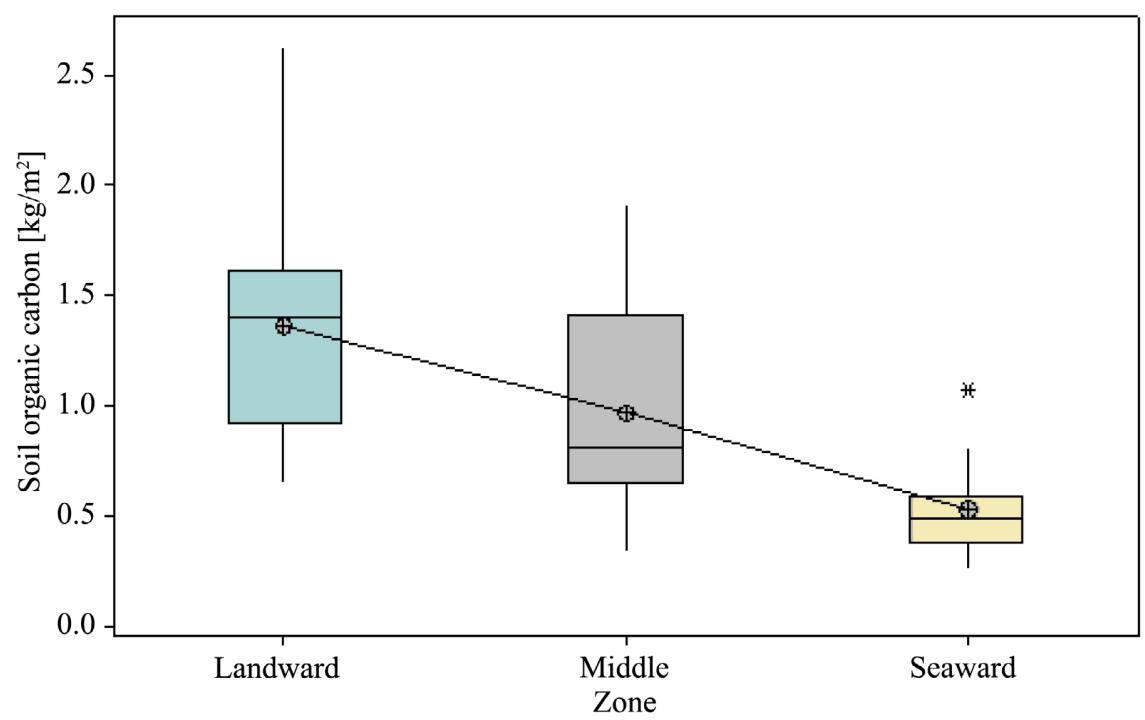

Figure 11. Analysis of variance of soil organic carbon between the three zones $(P<$ $0.001)$.

Table 4. Soil parameters in Al-Qurm nature reserve (mean \pm SD).

\begin{tabular}{cccc}
\hline parameters & seaward & middle & landward \\
\hline Bulk density $\left(\mathrm{g} / \mathrm{cm}^{3}\right)$ & $0.85 \pm 0.04$ & $0.87 \pm 0.03$ & $0.93 \pm 0.03$ \\
Soil organic carbon $\left(\mathrm{Kg} \mathrm{C} / \mathrm{m}^{2}\right)$ & $0.52 \pm 0.24$ & $0.97 \pm 0.49$ & $1.36 \pm 0.58$ \\
TOC (Total Organic Carbon) \% & $0.21 \pm 0.100$ & $0.37 \pm 0.19$ & $0.48 \pm 0.20$ \\
TOC (Total Organic Carbon) $\mathrm{g} / \mathrm{kg}$ & $2.07 \pm 0.98$ & $3.69 \pm 1.85$ & $4.84 \pm 1.98$ \\
\hline
\end{tabular}

Table 5. Average of total organic carbon (TOC) $\mathrm{g} \mathrm{C} / \mathrm{kg}$ and soil organic carbon (SOC) pool $\mathrm{kg} \cdot \mathrm{C} / \mathrm{m}^{2}$ in this study compared with those estimated by researchers in neighbouring countries and around.

\begin{tabular}{|c|c|c|c|c|}
\hline Location & TOC & SOC & Depth $(\mathrm{cm})$ & Reference \\
\hline Red Sea coast, Kingdom of Saudi Arabia & 16.1 & 9.2 & 50 & Shaltout et al. (2020) \\
\hline Red Sea coast, Egypt & 15.7 & 8.6 & 40 & Eid \& Shaltout (2016) \\
\hline Arabian Gulf, United Arab Emirates & & $10.2-15.6$ & 100 & Schile et al. (2017) \\
\hline North east Coast, Qatar & & 5.0 & 100 & Chatting et al. (2020) \\
\hline Jask area, Iran & & 6.0 & 42 & Etemadi et al. (2018) \\
\hline $\begin{array}{c}\text { Al-Qurm nature reserve, } \\
\text { Oman Sea coast, Sultanate of Oman }\end{array}$ & 3.5 & 0.95 & 30 & This study \\
\hline
\end{tabular}

The mean carbon stock in landward zone was $20.2 \pm 0.3 \mathrm{~kg} \cdot \mathrm{C} / \mathrm{m}^{2}$ (vegetation $18.8 \pm 0.1 \mathrm{~kg} \cdot \mathrm{C} / \mathrm{m}^{2}$ and sediment $1.4 \pm 0.3 \mathrm{~kg} \cdot \mathrm{C} / \mathrm{m}^{2}$ ); for middle zone was $8.7 \pm$ 0.4 (vegetation $7.7 \pm 0.3 \mathrm{~kg} \cdot \mathrm{C} / \mathrm{m}^{2}$ and sediment $1.0 \pm 0.2 \mathrm{~kg} \cdot \mathrm{C} / \mathrm{m}^{2}$ ) and for seaward, it was $5.8 \pm 0.8 \mathrm{~kg} \cdot \mathrm{C} / \mathrm{m}^{2}$ (vegetation $5.3 \pm 0.7 \mathrm{~kg} \cdot \mathrm{C} / \mathrm{m}^{2}$ and sediment $0.5 \pm$ $0.1 \mathrm{~kg} \cdot \mathrm{C} / \mathrm{m}^{2}$ ). The total mean carbon stock, including above-ground biomass, 
below-ground biomass and sediment carbon stock of Al-Qurm Nature Reserve (QNR), was estimated to be $11.6 \pm 1.7 \mathrm{~kg} \cdot \mathrm{C} / \mathrm{m}^{2}$, equivalent to $42.6 \mathrm{~kg} \mathrm{CO} / \mathrm{m}^{2}$. The mean carbon stock in the landward zone being higher than the seaward and middle zone may be due to freshwater discharge via land into the sea. The carbon stock is distributed predominantly on the above-ground biomass $(60 \%)$, followed by below-ground (32\%) and sediment (8\%). The total area of Al-Qurm Nature Reserve (QNR) is $0.82 \mathrm{~km}^{2}$. The value of the mean stock was extrapolated and estimated that a substantial sink capacity of $9512 \mathrm{t}$ of $\mathrm{C}(0.0095 \mathrm{Mt})$ is equivalent to $0.035 \mathrm{Mt}$ of $\mathrm{CO}_{2} \mathrm{e}$. These estimates suggest the high carbon storage and carbon sequestration potential of Al-Qurm Nature Reserve (QNR), besides the provision of other ecosystem services.

Bulmer et al. (2016) estimated the mean carbon stock of temperate Avicennia marina mangroves in New Zealand to have $11.7 \mathrm{~kg} \cdot \mathrm{C} / \mathrm{m}^{2} \pm 1.7 \mathrm{~kg} \cdot \mathrm{C} / \mathrm{m}^{2}$ for above-ground below-ground and sediments at $100 \mathrm{~cm}$ depth. This result was similar to the result obtained from this study $\left(11.6 \pm 1.7 \mathrm{~kg} \cdot \mathrm{C} / \mathrm{m}^{2}\right)$. Although Oman is located in an arid and semi-arid region, mangrove trees can sequester and store a higher amount of carbon dioxide from the atmosphere. The limitation of the study is that it focused only on $0-30-\mathrm{cm}$ sediment for the SOC pool. However, several studies have reported that sediment organic carbon (SOC) may extend up to several meters in depth (Bouillon et al., 2003; Lallier-Verges et al., 1998; Twilley et al., 1992). Thus, actual mangrove ecosystem carbon stock may be much higher than the value estimated in this study.

\section{Conclusion}

There is a clear distinction in DBH distribution among the 3 zones. The 3 stratified zones, landward, middle, seaward, showed a significant difference in their capacities to sequester carbon in their above and below-ground biomass. The landward zone has the highest value of above-ground, and below-ground carbon since more mature trees with a high circumference is found in this zone despite lower tree density. In contrast, the seaward zone has the lowest value for both above and below-ground carbon. There was a strong relationship between above-ground carbon and below-ground carbon. The regression model that obtained the relationship between field measurements and Normalized Differential Vegetation Index was moderate $(\mathrm{R}=0.53)$. However, the above-ground biomass was marginally an underestimate compared to the field measurement. Sediment organic carbon showed a significant difference between zones with the highest value found in landward, positively correlated with the above-ground biomass. Generally, the SOC pool is relatively low in the Al-Qurm nature reserve, as this study sampled only the upper $30 \mathrm{~cm}$ of the sediment. This relatively low value might not reflect the actual amount since many research worldwide found more organic carbon in the sediment at higher depths. The carbon sequestration service of this small nature reserve is believed to serve as an impact evidence for the decision makers to sustainably conserve this unique habitat against all pressing developmental needs in the future. 


\section{Conflicts of Interest}

The authors declare no conflicts of interest regarding the publication of this paper.

\section{References}

Abohassan, R. A. A., Okia, C. A., Agea, J. G., Kimondo, J. M., \& McDonald, M. M. (2012). Perennial Biomass Production in Arid Mangrove Systems on the Red Sea Coast of Saudi Arabia. Environmental Research Journal, 6, 22-31.

Adame, M. F., Santini, N. S., Tovilla, C., Vázquez-Lule, A., Castro, L., \& Guevara, M. (2015). Carbon Stocks and Soil Sequestration Rates of Tropical Riverine Wetlands. Biogeosciences, 12, 3805-3818. https://doi.org/10.5194/bg-12-3805-2015

Alavaisha, E., \& Mangora, M. M. (2016). Carbon Stocks in the Small Estuarine Mangroves of Geza and Mtimbwani, Tanga, Tanzania. International Journal of Forestry Research, 2016, Article ID: 2068283. https://doi.org/10.1155/2016/2068283

Alsumaiti, T. S. S. (2014). Structure, Aboveground Biomass, and Soil Characterization of Avicennia marina in Eastern Mangrove Lagoon National Park, Abu Dhabi. University of Arkansas.

Bouillon, S., Dahdouh-Guebas, F., Rao, A. V. V. S., Koedam, N., \& Dehairs, F. (2003). Sources of Organic Carbon in Mangrove Sediments: Variability and Possible Ecological Implications. Hydrobiologia, 495, 33-39. https://doi.org/10.1023/A:1025411506526

Bulmer, R. H., Schwendenmann, L., \& Lundquist, C. J. (2016). Allometric Models for Estimating Aboveground Biomass, Carbon and Nitrogen Stocks in Temperate Avicennia marina Forests. Wetlands, 36, 841-848.

https://doi.org/10.1007/s13157-016-0793-0

Chatting, M., LeVay, L., Walton, M., Skov, M. W., Kennedy, H., Wilson, S., \& Al-Maslamani, I. (2020). Mangrove Carbon Stocks and Biomass Partitioning in an Extreme Environment. Estuarine, Coastal and Shelf Science, 244, Article ID: 106940. https://doi.org/10.1016/j.ecss.2020.106940

Clough, B. F., Dixon, P., \& Dalhaus, O. (1997). Allometric Relationships for Estimating Biomass in Multi-Stemmed Mangrove Trees. Australian Journal of Botany, 45, 1023. https://doi.org/10.1071/BT96075

Comley, B. W. T., \& McGuinness, K. A. (2005). Above- and Below-Ground Biomass, and Allometry, of Four Common Northern Australian Mangroves. Australian Journal of Botany, 53, 431. https://doi.org/10.1071/BT04162

Cookson, P., \& Lepiece, A. (1997). Classification of Soils Supporting Mangroves in the Sultan Qaboos Qurm Nature Reserve (Oman). Journal of King Abdulaziz University-Marine Sciences, 8, 149-168. https://doi.org/10.4197/mar.8-1.10

Dodd, R. S., Blasco, F., Rafii, Z. A., \& Torquebiau, E. (1999). Mangroves of the United Arab Emirates: Ecotypic Diversity in Cuticular Waxes at the Bioclimatic Extreme. $A q$ uatic Botany, 63, 291-304. https://doi.org/10.1016/S0304-3770(98)00124-7

Eid, E. M., \& Shaltout, K. H. (2016). Distribution of Soil Organic Carbon in the Mangrove Avicennia marina (Forssk.) Vierh. along the Egyptian Red Sea Coast. Regional Studies in Marine Science, 3, 76-82. https://doi.org/10.1016/j.rsma.2015.05.006

Eid, E. M., El-Bebany, A. F., \& Alrumman, S. A. (2016). Distribution of Soil Organic Carbon in the Mangrove Forests along the Southern Saudi Arabian Red Sea Coast. Rendiconti Lincei, 27, 629-637. https://doi.org/10.1007/s12210-016-0542-6

Etemadi, H., Smoak, J. M., \& Sanders, C. J. (2018). Forest Migration and Carbon Sources 
to Iranian Mangrove Soils. Journal of Arid Environments, 157, 57-65. https://doi.org/10.1016/j.jaridenv.2018.06.005

Fan, B., Li, Y., \& Pavao-Zuckerman, M. (2020). The Dynamics of Land-Sea-Scape Carbon Flow Can Reveal Anthropogenic Destruction and Restoration of Coastal Carbon Sequestration. Landscape Ecology, 36, 1933-1949.

https://doi.org/10.1007/s10980-020-01148-9

Fan, K. C. (2008). Population Structure, Allometry and Above-Ground Biomass of Avicennia marina Forest at the Chishui River Estuary, Tainan County, Taiwan. Quarterly Journal of Forestry Research, 30, 1-15.

Friess, D. A., Richards, D. R., \& Phang, V. X. H. (2015). Mangrove Forests Store High Densities of Carbon across the Tropical Urban Landscape of Singapore. Urban Ecosystems, 19, 795-810. https://doi.org/10.1007/s11252-015-0511-3

Fromard, F., Puig, H., Mougin, E., Marty, G., Betoulle, J. L., \& Cadamuro, L. (1998). Structure, Above-Ground Biomass and Dynamics of Mangrove Ecosystems: New Data from French Guiana. Oecologia, 115, 39-53. https://doi.org/10.1007/s004420050489

Hamdan, O., Khairunnisa, M. R., Ammar, A. A., Hasmadi, I. M., \& Aziz, H. K. (2013). Mangrove Carbon Stock Assessment by Optical Satellite Imagery. Journal of Tropical Forest Science, 25, 554-565.

Kandasamy, K., Rajendran, N., Balakrishnan, B., Thiruganasambandam, R., \& Narayanasamy, R. (2021). Carbon Sequestration and Storage in Planted Mangrove Stands of Avicennia marina. Regional Studies in Marine Science, 43, Article ID: 101701. https://doi.org/10.1016/j.rsma.2021.101701

Kauffman, J. B., Heider, C., Cole, T. G., Dwire, K. A., \& Donato, D. C. (2011). Ecosystem Carbon Stocks of Micronesian Mangrove Forests. Wetlands, 31, 343-352. https://doi.org/10.1007/s13157-011-0148-9

Komiyama, A., Ong, J. E., \& Poungparn, S. (2008). Allometry, Biomass, and Productivity of Mangrove Forests: A Review. Aquatic Botany, 89, 128-137. https://doi.org/10.1016/j.aquabot.2007.12.006

Kovacs, J. M., de Santiago, F. F., Bastien, J., \& Lafrance, P. (2010). An Assessment of Mangroves in Guinea, West Africa, Using a Field and Remote Sensing Based Approach. Wetlands, 30, 773-782. https://doi.org/10.1007/s13157-010-0065-3

Lallier-Verges, E., Perrussel, B. P., Disnar, J. R., \& Baltzer, F. (1998). Relationships between Environmental Conditions and the Diagenetic Evolution of Organic Matter Derived from Higher Plants in a Modern Mangrove Swamp System (Guadeloupe, French West Indies). Organic Geochemistry, 29, 1663-1686. https://doi.org/10.1016/S0146-6380(98)00179-X

Li, X., Yeh, A., Liu, K., \& Wang, S. (2006). Inventory of Mangrove Wetlands in the Pearl River Estuary of China Using Remote Sensing. Journal of Geographical Sciences, 16, 155-164. https://doi.org/10.1007/s11442-006-0203-2

Liu, H., Ren, H., Hui, D., Wang, W., Liao, B., \& Cao, Q. (2014). Carbon Stocks and Potential Carbon Storage in the Mangrove Forests of China. Journal of Environmental Management, 133, 86-93. https://doi.org/10.1016/j.jenvman.2013.11.037

Manna, S., Nandy, S., Chanda, A., Akhand, A., Hazra, S., \& Dadhwal, V. K. (2014). Estimating Aboveground Biomass in Avicennia marina Plantation in Indian Sundarbans Using High-Resolution Satellite Data. Journal of Applied Remote Sensing, 8, Article ID: 083638. https://doi.org/10.1117/1.JRS.8.083638

Mashaly, I. A., Hegazy, A. K., Aal, M. A., \& El-Hussieny, S. A. (2016). Habitat-Based Estimate of Carbon Content in Mangrove Avicennia marina (Forssk.) Vierh. of South Sinai, Egypt. IOSR Journal of Environmental Science, Toxicology and Food Technology, 
10, 8-14.

MECA (2014). 5th National Report of the Conservation on Biological Diversity (CBD). Ministry of Environmental and Climate Affairs, Sultanate of Oman.

Njana, M. A., Bollandsås, O. M., Eid, T., Zahabu, E., \& Malimbwi, R. E. (2015). Aboveand Belowground Tree Biomass Models for Three Mangrove Species in Tanzania: A Nonlinear Mixed Effects Modelling Approach. Annals of Forest Science, 73, 353-369. https://doi.org/10.1007/s13595-015-0524-3

Parvaresh, H., Parvaresh, E., \& Zahedi, G. (2012). Establishing Allometric Relationship Using Crown Diameter for the Estimation of Above-Ground Biomass of Grey Mangrove, Avicennia marina (Forsk) Vierh in Mangrove Forests of Sirik, Iran. Journal of Basic and Applied Scientific Research, 2, 1763-1769.

Patil, V., Singh, A., Naik, N., \& Unnikrishnan, S. (2013). Estimation of Carbon Stocks in Avicennia marina Stand Using Allometry, CHN Analysis, and GIS Methods. Wetlands, 34, 379-391. https://doi.org/10.1007/s13157-013-0505-y

Public Authority for Civil Aviation (2017). Directorate General of Meteorology, Research and Meteorological Development, Sultanate of Oman, Personally Collected Data in May 28, 2017.

Sahu, S. C., Kumar, M., \& Ravindranath, N. H. (2016). Carbon Stocks in Natural and Planted Mangrove Forests of Mahanadi Mangrove Wetland, East Coast of India. Current Science, 110, 2253. https://doi.org/10.18520/cs/v110/i12/2253-2260

Schile, L. M., Kauffman, J. B., Crooks, S., Fourqurean, J. W., Glavan, J., \& Megonigal, J. P. (2017). Limits on Carbon Sequestration in Arid Blue Carbon Ecosystems. Ecological Applications, 27, 859-874. https://doi.org/10.1002/eap.1489

Shaltout, K. H., Ahmed, M. T., Alrumman, S. A., Ahmed, D. A., \& Eid, E. M. (2020). Evaluation of the Carbon Sequestration Capacity of Arid Mangroves along Nutrient Availability and Salinity Gradients along the Red Sea Coastline of Saudi Arabia. Oceanologia, 62, 56-69. https://doi.org/10.1016/j.oceano.2019.08.002

Tran, P. (2014). Allometry, Biomass and Litter Decomposition of the New Zealand Mangrove Avicennia marina var. Australasica. Doctoral Dissertation, Auckland University of Technology.

Tue, N. T., Dung, L. V., Nhuan, M. T., \& Omori, K. (2014). Carbon Storage of a Tropical Mangrove Forest in Mui Ca Mau National Park, Vietnam. Catena, 121, 119-126. https://doi.org/10.1016/j.catena.2014.05.008

Twilley, R. R., Chen, R. H., \& Hargis, T. (1992). Carbon Sinks in Mangroves and Their Implications to Carbon Budget of Tropical Coastal Ecosystems. Water, Air, \& Soil Pollution, 64, 265-288. https://doi.org/10.1007/BF00477106

Wicaksono, P. (2017). Mangrove Above-Ground Carbon Stock Mapping of Multi-Resolution Passive Remote-Sensing Systems. International Journal of Remote Sensing, 38, 1551-1578. https://doi.org/10.1080/01431161.2017.1283072

Winarso, G., Vetrita, Y., Purwanto, A. D., Anggraini, N., Darmawan, S., \& Yuwono, D. M. (2017). Mangrove above Ground Biomass Estimation Using Combination of Landsat 8 and ALOS PALSAR Data. International Journal of Remote Sensing and Earth Sciences (IJReSES), 12, 85-96. https://doi.org/10.30536/j.ijreses.2015.v12.a2687 